\title{
Small Animal Models of Hepatitis E Virus Infection
}

\author{
Tian-Cheng Li and Takaji Wakita \\ Department of Virology II, National Institute of Infectious Diseases, Tokyo 208-0011, Japan \\ Correspondence: litc@nih.go.jp
}

\begin{abstract}
Novel hepeviruses have been recovered from many different animal species in recent years, increasing the diversity known to exist among the Hepeviridae, which now include two genera, Piscihepevirus and Orthohepevirus. Multiple viral genotypes in the Orthohepevirus A species are able to replicate and cause acute hepatitis $\mathrm{E}$ in humans, and thus represent an important public health problem in industrialized as well as developing countries. Although hepatitis E virus (HEV) infections typically result in acute and self-limited hepatitis, immunocompromised and transplant patients are vulnerable to prolonged infections and to chronic hepatitis. Cell culture systems have been established for several HEV strains and offer new opportunities for the study of HEV biology. Similarly, a variety of new small animal models have been developed, using either nonhuman hepeviruses in their cognate hosts as surrogates for human HEV, or human HEV infection of immunodeficient mice with chimeric livers engrafted with human hepatocytes. These new models provide several advantages over previous nonhuman primate models of hepatitis $\mathrm{E}$ infection and will facilitate studies of pathogenicity, cross-species infection, mechanisms of virus replication, and vaccine and antiviral agent development. This article reviews the current understanding of small animal models for HEV.
\end{abstract}

$\mathrm{H}$ epatitis E virus (HEV) is classified in the genus Hepevirus of the family Hepeviridae (Meng et al. 2012; Kenney and Meng 2018). It is a small, round nonenveloped virus, $27-34 \mathrm{~nm}$ in diameter. The genome of genotype (gt) $1 \mathrm{HEV}$ was first molecularly cloned in 1990 (Reyes et al. 1990) and is a 7.2-kb, single-strand, positivesense RNA molecule containing three discontinuous and partially overlapping open reading frames (ORFs) (Tam et al. 1991). The $5^{\prime}$ end of the RNA terminates in an $\mathrm{m}^{7} \mathrm{G}$ cap structure, and the $3^{\prime}$ terminus of the RNA is polyadenylated (Tam et al. 1991; Magden et al. 2001). ORF1 encodes a large polyprotein with several putative functional domains, but it is unclear whether this polyprotein undergoes proteolytic processing resulting in separate mature nonstructural proteins as in other positive-strand viruses. ORF2 encodes the major capsid protein, which self-assembles into virus-like particles (VLPs) when expressed by recombinant baculoviruses (Li et al. 2000, 2011). ORF3 encodes a phosphoprotein with multiple functions and is associated with virion release in particular (Nagashima et al. 2011).

HEV causes waterborne epidemic and sporadic acute hepatitis $\mathrm{E}$ in developing countries and sporadic, zoonotic infections in devel-

Editors: Stanley M. Lemon and Christopher Walker

Additional Perspectives on Enteric Hepatitis Viruses available at www.perspectivesinmedicine.org

Copyright (C) 2019 Cold Spring Harbor Laboratory Press; all rights reserved; doi: 10.1101/cshperspect.a032581

Cite this article as Cold Spring Harb Perspect Med 2019;9:a032581 
oped countries (Emerson and Purcell 2003; Nelson et al. 2011, 2018; Dalton and Izopet 2018). HEVs isolated from humans are grouped into four major genotypes designated 1 to 4 (gt1 to gt4) on the basis of their nucleotide and deduced amino acid sequences (Liu et al. 2008). HEV gt1 and gt2, which infect only humans, are transmitted primarily by the fecal-oral route (Balayan et al. 1983). They infect $\sim 20$ million people every year and cause waterborne hepatitis outbreaks in regions of Asia, Africa, and Central America with low standards of sanitation. HEV gt 1 and gt 2 viruses cause $\sim 70,000$ deaths every year (Rein et al. 2012) with very high morbidity in pregnant women who have a mortality risk as high as 20\% (Khuroo et al. 1981).

Human HEV gt 3 and gt4 infections occur most commonly in developed countries of Europe, the Americas, and Asia. These infections are sporadic and very likely zoonotic in nature, transmitted to humans from species that include domesticated pigs, wild boar, and deer (Tei et al. 2003; Li et al. 2005; Meng 2010). Probable zoonotic transmission of an HEV gt7 virus from a camel also has been described recently (Lee et al. 2015). Because HEV infection is associated with viremia, HEV may also be transmitted by blood transfusion. Importantly, such autochthonous hepatitis $\mathrm{E}$ infections can persist in immunocompromised individuals, including transplant recipients as well as patients with hematologic malignancies or poorly controlled human immunodeficiency virus (HIV) infection (Kamar et al. 2013).

In addition to human HEV, novel HEV-like viruses have been identified in a wide variety of animal species, including wild boars, monkeys, rabbits, rats, minks, moose, ferrets, red foxes, camels, kestrel, little egrets, chickens, bats, and cutthroat trout (Haqshenas et al. 2001; Zhao et al. 2009; Johne et al. 2010a; Batts et al. 2011; Drexler et al. 2012; Raj et al. 2012; Yamamoto et al. 2012; Bodewes et al. 2013; Krog et al. 2013; Lin et al. 2014; Takahashi et al. 2014; Woo et al. 2014; Reuter et al. 2016). The family Hepeviridae is comprised of two genera, Orthohepevirus and Piscihepevirus (Smith et al. 2014; see also Smith and Simmonds 2018), in a classification scheme recently approved by the International Com- mittee on Taxonomy of Viruses (ICTV) (see ictvonline.org/virusTaxonomy.asp). The Orthohepevirus genus includes four species: Orthohepevirus $A$, which includes isolates from humans, monkeys, pigs, wild boar, deer, mongoose, rabbits, and camels; Orthohepevirus B, which includes isolates from chickens; Orthohepevirus $C$, which includes isolates from rats, greater bandicoots, Asian musk shrews, ferrets, and mink; and Orthohepevirus $D$, which includes isolates from bats. The species assignments of isolates from moose, kestrel, and little egrets remain uncertain. Cutthroat trout virus is classified within the genus Piscihepevirus.

Human, camel, rabbit, ferret, and rat HEV have been propagated in various cell lines, including human hepatocellular carcinoma cells (PLC/PRF/5 or HepG2), human lung cancer cells (A549), and several nonhuman mammalian cell lines (Tanaka et al. 2007; Shukla et al. 2011; Jirintai et al. 2012, 2014; Li et al. 2016c, d). Such cell culture systems are useful for understanding mechanisms of replication, cell entry, and virion morphogenesis. However, they do not allow investigation of the molecular basis underlying differences in the pathogenicity of HEV genotypes and the ability of gt 3 viruses to cause persistent infection.

Further progress in defining mechanisms of liver disease and immune control in humans with acute and chronic HEV infections will depend on the availability of suitable animal models. Development of approaches to prevent or treat severe acute infection, especially in the setting of pregnancy as well as chronic infections, would also be aided by an animal model that recapitulates features of human infection. Chimpanzees are susceptible to HEV and have been used to characterize virological and immunological aspects of HEV infection (Meng et al. 1998; Yu et al. 2010; Purcell et al. 2013; Lanford et al. 2018). However, these animals are no longer available for invasive biomedical research. Other nonhuman primates ( particularly macaque species) and swine also have been used to model acute (Balayan et al. 1983, 1990; Halbur et al. 2001; Li et al. 2004, 2016d; Meng 2010; Purcell et al. 2013) and more recently persistent HEV infection in the setting of immune suppression 
(Cao et al. 2017; Gardinali et al. 2017). Cynomolgus and rhesus monkeys are susceptible to gt1-4 and gt7 HEV infection and were useful in evaluating the response to HEV vaccine candidates as detailed in Lanford et al. (2018). Swine also can be readily infected with gt 3 and gt 4 $\mathrm{HEV}$, with mild or no disease, and are a likely reservoir for gt3 and gt4 HEV (Halbur et al. 2001). These nonhuman primate and swine models are potentially very useful, but they are expensive and cumbersome for studies of HEV pathogenesis. Moreover, they do not always recapitulate clinical aspects of hepatitis E, showing minimal elevations in serum liver enzymes and only moderate pathological liver lesions (Halbur et al. 2001; Meng 2010; Cullen and Lemon 2018). In this review, we focus on HEV infection models using small animals, including rabbits, ferrets, rats, tree shrews, Mongolian gerbils, and mice with chimeric human livers.

\section{RABBITS (Oryctolagus sp.)}

Rabbit (Oryctolagus sp.) HEV was first detected in farmed rabbits from China. Analysis of the full-length genomic sequences showed that rabbit HEV strains are most closely related to the gt3 HEV, which causes zoonotic infections in humans (Zhao et al. 2009). Since then, many rabbit HEV strains have been detected in farmed as well as wild and specific pathogenfree (SPF) rabbits in the United States, China, Korea, Germany, Italy, the Netherlands, and France (Cossaboom et al. 2011; Burt et al. 2016; Di Bartolo et al. 2016; Ahn et al. 2017; Hammerschmidt et al. 2017; Liu et al. 2017), suggesting that $\mathrm{HEV}$ infection is common in rabbits and that they are a natural host for this virus. Rabbit HEV replicated in PLC/PRF/5 and A549 cell lines as efficiently as gt $3 \mathrm{HEV}$ (Jirintai et al. 2012). Of $919 \mathrm{HEV}$-infected patients studied in France during 2015-2016, five were infected with virus closely related to rabbit $\mathrm{HEV}$, suggesting that rabbit $\mathrm{HEV}$ strains may be transmitted to humans and cause occasional zoonotic infection (Abravanel et al. 2017). Rabbit HEV has been successfully transmitted to pigs (Cossaboom et al. 2012) and cynomolgus macaques (Liu et al. 2013), confirming the po- tential for cross-species transmission (Liu et al 2017).

Experimental infection studies indicate that rabbits shed virus in feces, develop antibodies to $\mathrm{HEV}$, and show elevations in serum alanine aminotransferase (ALT) activity indicative of acute liver damage when infected with HEV (Ma et al. 2010). Intriguingly, experimental infection of pregnant rabbits with rabbit HEV resulted in high mortality as well as vertical transmission of virus, with local hepatocellular necrosis evident in microscopic evaluation of the liver (Xia et al. 2015). In contrast, nonpregnant rabbits experimentally infected with rabbit HEV demonstrated little to no overt signs of disease.

The close genetic and antigenic relatedness of rabbit HEV to other mammalian HEV strains suggests that infected rabbits may serve as a useful, naturally occurring animal model for the study of HEV pathogenesis. However, rabbits do not appear to be uniformly susceptible to infection with HEV strains that infect humans. In one study, gt1 HEV was not infectious for rabbits, and although rabbits inoculated with gt3 HEV seroconverted they demonstrated neither viremia nor fecal viral shedding (Cheng et al. 2012). Similarly, intravenous and oral inoculation of gt $4 \mathrm{HEV}$ resulted in infection in only some rabbits. Another report confirmed that only two of nine rabbits inoculated with gt4 HEV became infected, and that gt $1 \mathrm{HEV}$ was incapable of eliciting any markers of HEV infection in rabbits (Ma et al. 2010). Our preliminary experimental results also suggest that rabbits are not susceptible to gt7 HEV infection.

In summary, although rabbits cannot be reliably infected with human HEV strains, rabbits infected with rabbit HEV may provide an appropriate parallel animal model of HEV infection, especially in the medically important setting of pregnancy for which no other animal model of enhanced maternal disease currently exists.

\section{FERRETS (Mustela putorius)}

Ferrets ( $M$. putorius), which have long been used as an animal model of influenza virus infection, may also be valuable for the study of 
T.-C. Li and T. Wakita

HEV infection. HEV was first detected in ferrets from the Netherlands in 2012 (Raj et al. 2012), but since then many other ferret HEV strains have been identified in ferrets used as laboratory animals or kept as pets in the United States and Japan (Raj et al. 2012; Yang et al. 2013; Li et al. 2015b). Ferret HEV is distinct from human $\mathrm{HEV}$ and is widespread among ferrets in Europe, the Americas, and Asia.

The ferret HEV genome contains the three ORFs (1-3) present in the human HEV genome. amino acids (aa), ORF2 encodes a capsid protein of 654 aa, and ORF3 encodes a phosphoprotein of 108 aa (Raj et al. 2012). A putative fourth ORF (ORF4) overlapping with ORF1 was also identified in the ferret HEV genome but is of unknown function. Ferret HEV is rather distantly related to human HEV strains and shares the highest nucleotide sequence identity $(72.3 \%)$ with rat HEV (Fig. 1). Nucleotide sequence identity with human gt1-gt4 $\mathrm{HEV}$, rabbit and avian HEVs ranges from $54.5 \%$ to $60.5 \%$ (Raj et al. 2012). However, antigenic analyses demonstrate

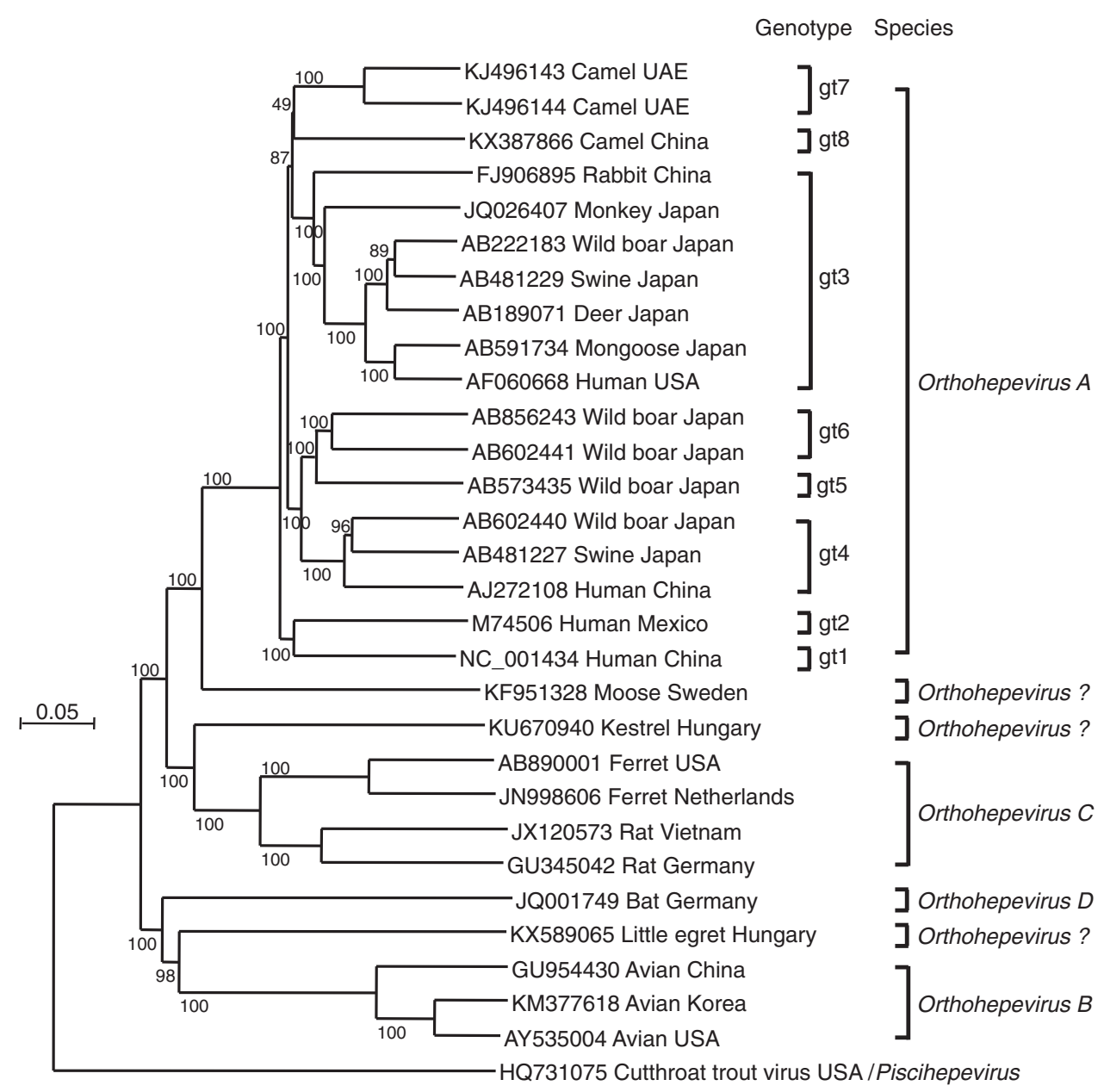

Figure 1. Phylogenetic tree based on complete genomic sequences of hepeviruses recovered from fish, humans, monkey, swine, wild boar, deer, rabbit, mongoose, camel, ferret, rat, moose, kestrel, little egret, and avian sources. Sources of hepatitis E virus (HEV) strains follow GenBank accession numbers. Sequence alignment was performed with ClustalW. Orthohepevirus species assignments are indicated on the right (see also Smith and Simmonds 2018). 
that ferret HEVs are cross-reactive with gt1, gt3, gt4, and rat HEVs. As might be expected from their greater nucleotide sequence identity, the rat and ferret HEVs showed stronger antigenic cross-reactivity to each other than either did to human HEV. However, antibody directed against ferret $\mathrm{HEV}$ does not neutralize gt3 $\mathrm{HEV}$, suggesting that these two HEVs belong to different serotypes (Yang et al. 2013).

The level of nucleotide sequence identity (full genome) between ferret HEV (classified within the species Orthohepevirus $C$ ) and human HEV gt1-gt4 (Orthohepevirus A) is $<55 \%$, and there is as yet no evidence for the zoonotic potential of ferret HEV. An infection experiment indicated that laboratory rats (Wistar), nude rats (Long Evans run/run), and cynomolgus macaques are also not susceptible to ferret $\mathrm{HEV}$, suggesting that the capacity of ferret HEV to replicate in other commonly used experimental animals is very limited ( $\mathrm{Li}$ et al. 2015c). However, a cell culture system has been established for ferret HEV using the human hepatocellular carcinoma cell line, PLC/PRF/5; infectious virus particles recovered from cell culture supernatants were shown to be associated with membranes (Li et al. 2016c).

Like other HEVs, ferret HEV can be transmitted by the fecal-oral route (Li et al. 2016c). Three patterns of infection in ferrets have been observed, including subclinical infection, acute hepatitis as measured by transaminase eleva- tions, and persistent infection. In one study, the ALT was increased in $65.8 \%$ (25 of 38 ) of naturally infected ferrets testing positive for ferret HEV RNA; ALT levels were higher than $2000 \mathrm{IU} / \mathrm{L}$ in some ferrets ( $\mathrm{Li}$ et al. 2016a). Histologic changes induced in the liver by ferret HEV infection have yet to be characterized ( $\mathrm{Li}$ et al. 2016a, 2017). ALT elevations have also been documented after experimental transmission of the virus to ferrets, suggesting that liver disease is caused solely by ferret HEV and not a coinfecting virus (Fig. 2) (Li et al. 2016a).

Importantly, we recently identified persistent HEV infection in six of 63 ferrets imported into Japan from a ferret farm in the United States (Li et al. 2016a). Animals were viremic through at least 130 days of follow-up. It is notable that this persistent infection developed naturally in ferrets not treated with immune suppressive drugs. Naturally occurring persistent gt3 HEV infection has also been described in a captive Japanese snow monkey (Macaca fuscata) (Yamamoto et al. 2012) that served as a source of virus for other macaques in the colony. Why some ferrets and monkeys develop prolonged or persistent infections in the absence of immune-suppressive therapy remains unclear. Ferrets may be particularly useful in efforts to define factors leading to persistence and to identify protective immune responses to HEV. Such studies may provide a better understanding of persistent HEV infections occurring in solid-

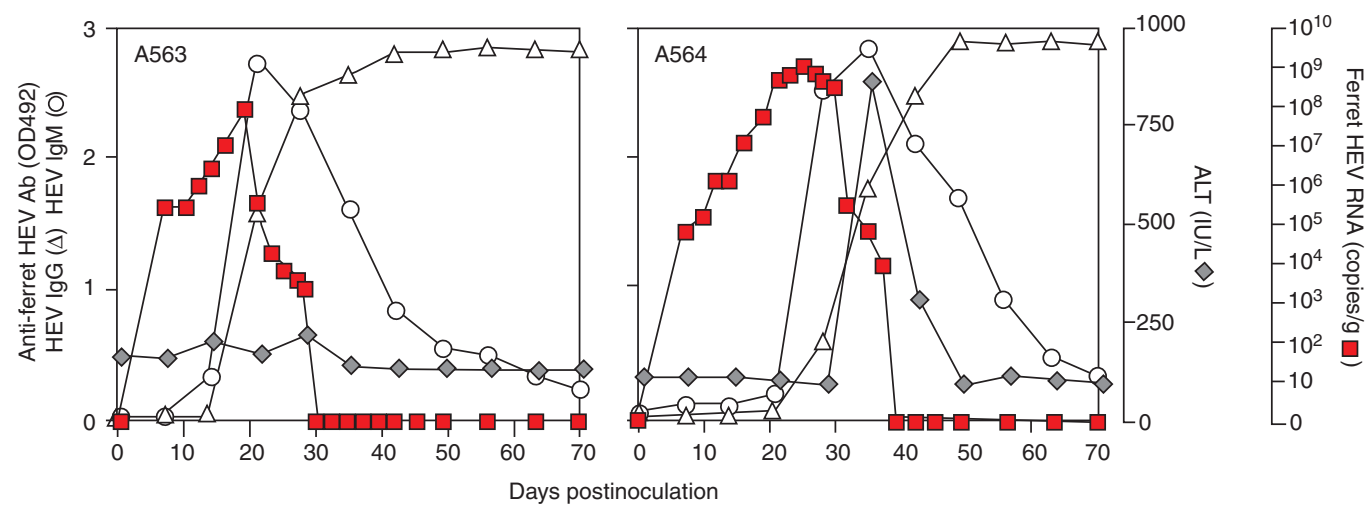

Figure 2. Experimental infection of ferrets with ferret hepatitis E virus (HEV). Animals were inoculated orally with virus recovered from the supernatant fluids of infected PLC/PRF/5 cells. (From Li et al. 2016a; adapted, with permission, from Elsevier (c) 2016.) 
organ transplant recipients who have received immunosuppressive drugs, and in patients with other immunosuppressive conditions, including HIV infection and hematological malignancy (Kamar et al. 2008; Dalton et al. 2009; le Coutre et al. 2009; Ollier et al. 2009). It will be also interesting to determine whether persistent HEV infection is associated with chronic hepatitis and triggers the onset of hepatic cirrhosis or even hepatocellular carcinoma.

\section{RATS (Rattus sp.) AND NUDE RATS}

Rat HEV was first identified in 2010 in feces of wild rats (Rattus sp.) from Germany (Johne et al. 2010a). Since then, the virus has been detected in animals from several countries in Europe and Asia and from the United States (Johne et al. 2014). The host species are mainly rat species (Rattus norvegicus, Rattus rattus, among other), but viruses very closely related to rat $\mathrm{HEV}$ have also been found in the greater bandicoot (Bandicota indica) and the Asian musk shrew (Suncus murinus) (Guan et al. 2013; Li et al. 2013a,b). Phylogenetic analyses indicate that rat $\mathrm{HEV}$ is most closely related to ferret HEV (Fig. 1) (Raj et al. 2012), and both viruses have been classified with the Orthohepevirus $C$ species (Smith et al. 2014). Like the ferret HEV genome, the rat HEV genome also contains four ORFs, including ORFs 1-3, which encode a nonstructural polyprotein, the capsid protein, and a small phosphoprotein, respectively, and which are present in all HEV-related viruses. ORF4 overlaps with the $5^{\prime}$ region of ORF1, and as in the ferret virus is of unknown function (Johne et al. 2010b). Initial studies failed to show replication of rat HEV in rat-derived cell lines (Johne et al. 2010a). However, rat HEV has been propagated successfully in the human hepatoma cell lines PLC/PRF/5, HuH-7, and HepG2 (Jirintai et al. 2014).

Analyses of the amount of rat HEV-RNA present in different tissues of infected wild rats suggest that the virus is hepatotropic (Johne et al. 2010a). This was confirmed in laboratory rats intravenously inoculated with tissue homogenates containing rat HEV (Guan et al. 2013). Immunodeficient nude rats inoculated with rat $\mathrm{HEV}$ developed persistent infections with long-term shedding of large quantities of virus (Guan et al. 2013). In contrast, experimentally infected Wistar rats showed transient virus shedding and developed antirat HEV-specific antibodies. Hepatitis was not observed after experimental infections of rats (Purcell et al. 2011; Guan et al. 2013). These results suggest that rat HEV might provide an infection model but is unlikely to be helpful for studies of pathogenesis.

Because nude rats were found to be highly susceptible to rat HEV infection, with prolonged shedding of high titers of rat $\mathrm{HEV}$, we used these animals to develop a reverse molecular genetics system for the virus (Li et al. 2015a). Rat HEV was recovered from nude rats without any changes in its genome. The rat HEV-infected nude rats showed persistent infection that could be useful as an animal model for antiviral agent screening. In fact, ribavirin effectively inhibited replication of the LA-B350 strain of rat HEV in athymic nude rats, confirming the suitability of the rat model for antiviral studies (Debing et al. 2016).

The zoonotic potential of rat HEV is not clear at present. Efforts to experimentally infect rhesus monkeys and pigs with rat HEV did not result in evidence of virus replication (Purcell et al. 2011; Cossaboom et al. 2012). In addition, rats and even nude rats were not susceptible to experimental infection by HEV gt1-4 (Guan et al. 2013; Li et al. 2016b), suggesting that rats are not suitable for studying human HEV.

\section{MONGOLIAN GERBILS (Meriones unguiculatus)}

Several reports suggest the possibility of using Mongolian gerbils (M. unguiculatus) as an animal model of HEV infection. In one study, 14 Mongolian gerbils were successfully infected after intraperitoneal inoculation of gt $4 \mathrm{HEV}$ recovered from swine (Li et al. 2009). Viremia and fecal virus shedding persisted for nearly 4 weeks; virus was also detected within the liver as well as the kidneys, spleen, and small intestine. Histopathological changes included multifocal, lymphohistiocytic infiltrates, portal tracts, or irregular distribution throughout the parenchyma. HEV antigens were detected in the liver and 
intestine. In another study, gt1 HEV-infected gerbils showed histopathological changes within the liver, spleen, and kidney (Hong et al. 2015). HEV RNA was detected in fecal samples from 7 to 42 days after inoculation, but ALT levels were only moderately increased. However, in both of these studies, HEV-specific antibodies could not be detected in HEV-infected animals. Further studies will be needed to confirm whether Mongolian gerbils are truly susceptible to human $\mathrm{HEV}$ infection.

\section{TREE SHREWS (Tupaia belangeri chinensis)}

Tree shrews ( $T$. belangeri chinensis) are small Euarchonta mammals native to the tropical forests of Southeast Asia. Because they are closely related to primates, tree shrews have been studied in the past as potential animal models of hepatitis $B$ virus (HBV) and hepatitis $C$ virus $(\mathrm{HCV})$ infection. A recent study suggests that tree shrews can be infected with human gt4 $\mathrm{HEV}$ RNA, resulting in detection of $\mathrm{HEV}$ RNA in the serum, stool, liver, bile, spleen, and kidney tissue (Yu et al. 2016). HEV capsid protein was detected in the liver, spleen, and kidneys. The histological examination of the liver and serum ALT elevations were indicative of mild liver injury. Both immunoglobulin (Ig)G and IgM antibodies were detected in experimentally infected animals (Yu et al. 2016). Interestingly, uninoculated animals cohoused with experimentally infected animals also developed evidence of infection. The potential of tree shrews to serve as a model of human HEV infection merits further study.

\section{MURINE XENOGRAFT MODELS OF HEV INFECTION}

Infections of rats and ferrets with their cognate Orthohepevirus $C$ viruses provide interesting opportunities for studying general features of HEV infection, but these small animal species are not permissive for replication of the Orthohepevirus $A$ viruses that cause disease in humans. A murine model of hepatitis $\mathrm{E}$ would be particularly valuable given recent advances in murine genetics and the abundance of tools and reagents available to study infections in mice. However, hepeviruses have not been isolated from mice, and C57BL/6 mice have been confirmed experimentally to be nonsusceptible to human HEV infection (Li et al. 2008). Humanized mice with chimeric human livers have contributed significantly to our understanding of pathobiology, virus-host interactions, and antiviral therapy for hepatitis B, C, and D. As described in Hirai-Yuki et al. (2018), Alb-uPA/ SCID beige mice engrafted with human hepatocytes (Mercer et al. 2001) also support replication of human hepatitis A virus (HAV). It is not surprising, therefore, that human liver chimeric mice are susceptible to $\mathrm{HEV}$ infection.

Allweiss et al. (2016) described the first human liver chimeric mouse model of HEV infection. uPA/SCID/beige (USB) mice repopulated with primary human hepatocytes were susceptible to HEV infection. Chimeric mice infected with a gt $1 \mathrm{HEV}$ showed a rapid increase in viremia and large quantities of virus in serum, liver, bile, and feces for $>25$ weeks. In contrast, viremia in gt $3 \mathrm{HEV}$-infected mice developed more slowly and resulted in lower amounts of virus in all analyzed tissues compared with the gt $1 \mathrm{HEV}$ infected animals. HEV-infected human hepatocytes could be visualized in these mice using HEV ORF2- and ORF3-specific antibodies and in situ hybridization probes complementary to HEV RNA (Allweiss et al. 2016). Humanized uPA-NOG (uPA ${ }^{+/+} \mathrm{NOD} /$ Shi-scid/IL2 $\left.\mathrm{R} \gamma^{-/-}\right)$ and FRG mice are also susceptible to gt1 or gt3 HEV infection (van de Garde et al. 2016; Sayed et al. 2017).

Thus, human liver chimeric mice represent an attractive small animal model for the study of $\mathrm{HEV}$ infection and replication as well as the evaluation of novel antiviral and preventive strategies. As an example, it was recently shown that interferon $\alpha$ can rapidly clear HEV infection in humanized mice with chimeric livers (van de Garde et al. 2017), and that ribavirin can suppress virus replication (Allweiss et al. 2016). Moreover, such mice have been used to establish the infectious nature of HEV in human plasma, showing that it has the potential to cause transfusion-associated HEV infection (Sayed et al. 2017). These animals do lack a 


\section{T.-C. Li and T. Wakita}

functional immune system, however, and so studies of protective host immune responses may be limited to in vivo studies of virus neutralization by passively administered antibodies.

\section{CHICKEN MODEL OF AVIAN HEV}

A novel HEV strain was identified in 2001 in chickens in the United States with hepatitissplenomegaly syndrome (HSS) (Haqshenas et al. 2001). This virus is now classified within the Orthohepevirus B species (Fig. 1). There are at least three genotypes (gt1-gt3) of avian HEV distributed throughout the world, together sharing $\sim 60 \%$ nucleotide sequence identity with human HEV (Marek et al. 2010). Infections in chickens are often subclinical and result in mortality rates ranging from $0.3 \%$ to $1.0 \%$. Infection results from ingestion of the virus, and leads to subcapsular hemorrhages, focal lymphocytic

Table 1. Comparative features of hepatitis $\mathrm{E}$ virus (HEV) infection in macaques, swine, and small animal models of HEV infection

\begin{tabular}{|c|c|c|c|c|c|c|}
\hline \multirow[b]{2}{*}{ Species } & \multirow{2}{*}{$\begin{array}{l}\text { Known HEV } \\
\text { susceptibility }\end{array}$} & \multicolumn{2}{|c|}{ Infection outcome } & \multirow{2}{*}{$\begin{array}{c}\text { Severe } \\
\text { hepatitis in } \\
\text { pregnancy }\end{array}$} & \multicolumn{2}{|c|}{$\begin{array}{c}\text { Suitability for analysis } \\
\text { of immunity }\end{array}$} \\
\hline & & resolution & Persistence & & Humoral & Cellular ${ }^{\mathrm{a}}$ \\
\hline Macaque $^{b}$ & $\begin{array}{l}\text { Orthohepevirus } A \\
\text { gt } 1, \text { gt } 2, \text { gt } 3, \text { gt } 4 \text {, gt7 }\end{array}$ & Yes & $\begin{array}{l}\text { With immune } \\
\text { suppression }^{\mathrm{c}}\end{array}$ & $\mathrm{No}^{\mathrm{d}}$ & Yes & Strong \\
\hline Swine & $\begin{array}{l}\text { Orthohepevirus A } \\
\text { gt3, gt4 }\end{array}$ & Yes & $\begin{array}{l}\text { With immune } \\
\text { suppression }\end{array}$ & No & Yes & Strong \\
\hline Rabbit & $\begin{array}{l}\text { Orthohepevirus A rabbit } \\
\text { HEV (gt3), gt } 4\end{array}$ & Yes & Unknown & Yes & Yes & Poor \\
\hline Ferret & $\begin{array}{l}\text { Ferret HEV } \\
\quad \text { (Orthohepevirus C) }\end{array}$ & Yes & $\begin{array}{l}\text { Naturally } \\
\text { occurring } \\
\text { (frequency } \\
\text { unknown) }\end{array}$ & Unknown & Yes & Intermediate \\
\hline Rat & $\begin{array}{l}\text { Rat HEV } \\
\quad(\text { Orthohepevirus C) }\end{array}$ & Yes & Unknown & Unknown & Yes & Intermediate \\
\hline Chicken & $\begin{array}{l}\text { Chicken HEV } \\
\quad(\text { Orthohepevirus B) }\end{array}$ & Yes & Unknown & $\mathrm{N} / \mathrm{A}^{\mathrm{e}}$ & Yes & Poor \\
\hline $\begin{array}{l}\text { Mongolian } \\
\text { gerbil }\end{array}$ & $\begin{array}{l}\text { Orthohepevirus } A \\
\text { gt1, gt } 4\end{array}$ & Yes & Unknown & Unknown & Yes & Poor \\
\hline Tree shrew & $\begin{array}{l}\text { Orthohepevirus } A \\
\text { gt4 }\end{array}$ & Yes & Unknown & Unknown & Yes & Poor \\
\hline $\begin{array}{l}\text { Chimeric } \\
\text { mouse } \\
\text { (humanized } \\
\text { liver) }\end{array}$ & $\begin{array}{l}\text { Orthohepevirus } A \\
\text { gt } 1, \text { gt } 2, \text { gt } 3, \text { gt } 4\end{array}$ & No & Yes & N/A & Yes & No \\
\hline
\end{tabular}

${ }^{\text {a}}$ Suitability for studies of adaptive cellular immunity was classified as follows: "strong" when immunogenetic characterization of the species, availability of antibodies for detailed analysis of T-cell phenotype and function, and advanced reagents like major histocompatibility complex $(\mathrm{MHC})$ tetramers have been generated; "intermediate" when there are gaps in immunogenetic characterization and/or the array of available reagents for characterization of $\mathrm{T}$ cells; and "poor" when immunogenetics or reagents availability are limited.

${ }^{\mathrm{b} C y n o m o l g u s ~ a n d ~ r h e s u s ~ m a c a q u e s ~ u s e d ~ i n ~ m o s t ~ s t u d i e s ~(s e e ~ L a n f o r d ~ e t ~ a l . ~} 2018$ for details).

${ }^{c}$ As noted in the text (Yamamoto et al. 2012), naturally occurring persistent infection has been described in one captive Japanese macaque.

${ }^{d}$ Rhesus macaques infected with HEV gtl during pregnancy had no evidence of enhanced disease (Arankalle et al. 1993; Tsarev et al. 1995).

${ }^{\mathrm{e}} \mathrm{N} / \mathrm{A}$, Not applicable. 
periphlebitis, and hepatic phlebitis (Billam et al. 2005). Rhesus macaques were not susceptible to avian HEV infection when challenged experimentally, suggesting that avian HEV is probably not transmissible to primates (Huang et al. 2004). Similarly, chickens are not susceptible to human HEV infection. The usefulness of chickens as an animal model for human HEV is likely limited, but this naturally occurring chicken model offers a unique hepatic disease model (i.e., HSS) that might be used to study at least some aspects of human hepatitis E disease (Yugo et al. 2014).

\section{CONCLUDING REMARKS}

Novel hepeviruses have been identified in a variety of species, including small and readily available animals that are amenable to study in laboratory settings. Genomic characterization of these viruses has been important to sort out taxonomic relationships to $\mathrm{HEV}$ genotypes that infect humans, and to identify genetic features that might contribute to pathogenesis. At the same time, studies of virus replication, pathogenesis, and the nature of protective immune responses in these animals are somewhat preliminary. Further development of small animal models is nonetheless an imperative if mechanisms of progressive liver disease in chronic $\mathrm{HEV}$ infection and fulminant hepatitis $\mathrm{E}$ in pregnant women are to be understood. The ideal small animal model of HEV pathogenesis has yet to be identified (Table 1), but will ideally recapitulate the course of acute and chronic HEV infection in humans, and be amenable to studies of how innate and adaptive immunity might contribute to liver disease or provide protection from persistence.

\section{ACKNOWLEDGMENTS}

Our research on $\mathrm{HEV}$ has been supported in part by a Grant-in-Aid for Scientific Research (C) from Japan's Ministry of Education, Culture, Sports, Science and the Research Program on Hepatitis from the Japan Agency for Medical Research and Development (AMED 17fk0108218j0302 and 17fk0210301j1103).

\section{REFERENCES}

*Reference is also in this collection.

Abravanel F, Lhomme S, El Costa H, Schvartz B, Peron JM, Kamar N, Izopet J. 2017. Rabbit hepatitis E virus infections in humans, France. Emerg Infect Dis 23: 1191-1193.

Ahn HS, Park BJ, Han SH, Kim YH, Kim DH, Kim BS, Lee JB, Park SY, Song CS, Lee SW, et al. 2017. Prevalence and genetic features of rabbit hepatitis E virus in Korea. J Med Virol 89: 1995-2002.

Allweiss L, Gass S, Giersch K, Groth A, Kah J, Volz T, Rapp G, Schobel A, Lohse AW, Polywka S, et al. 2016. Human liver chimeric mice as a new model of chronic hepatitis $\mathrm{E}$ virus infection and preclinical drug evaluation. J Hepatol 64: 1033-1040.

Arankalle VA, Chadha MS, Banerjee K, Srinivasan MA, Chobe LP. 1993. Hepatitis E virus infection in pregnant rhesus monkeys. Indian J Med Res 97: 4-8.

Balayan MS, Andjaparidze AG, Savinskaya SS, Ketiladze ES, Braginsky DM, Savinov AP, Poleschuk VF. 1983. Evidence for a virus in non-A, non-B hepatitis transmitted via the fecal-oral route. Intervirology 20: 23-31.

Balayan MS, Usmanov RK, Zamyathina NA, Djumalieva DI, Karas FR. 1990. Brief report: Experimental hepatitis E infection in domestic pigs. J Med Virol 32: 58-59.

Batts W, Yun S, Hedrick R, Winton J. 2011. A novel member of the family Hepeviridae from cutthroat trout (Oncorhynchus clarkii). Virus Res 158: 116-123.

Billam P, Huang FF, Sun ZF, Pierson FW, Duncan RB, Elvinger F, Guenette DK, Toth TE, Meng XJ. 2005. Systematic pathogenesis and replication of avian hepatitis $\mathrm{E}$ virus in specific-pathogen-free adult chickens. J Virol 79: 34293437.

Bodewes R, van der Giessen J, Haagmans BL, Osterhaus AD, Smits SL. 2013. Identification of multiple novel viruses, including a parvovirus and a hepevirus, in feces of red foxes. J Virol 87: 7758-7764.

Burt SA, Veltman J, Hakze-van der Honing R, Schmitt H, van der Poel WH. 2016. Hepatitis E virus in farmed rabbits, wild rabbits and petting farm rabbits in the Netherlands. Food Environ Virol 8: 227-229.

Cao D, Cao QM, Subramaniam S, Yugo DM, Heffron CL, Rogers AJ, Kenney SP, Tian D, Matzinger SR, Overend C, et al. 2017. Pig model mimicking chronic hepatitis E virus infection in immunocompromised patients to assess immune correlates during chronicity. Proc Natl Acad Sci 114: 6914-6923.

Cheng X, Wang S, Dai X, Shi C, Wen Y, Zhu M, Zhan S, Meng J. 2012. Rabbit as a novel animal model for hepatitis E virus infection and vaccine evaluation. PLoS ONE 7: e51616.

Cossaboom CM, Cordoba L, Dryman BA, Meng XJ. 2011. Hepatitis E virus in rabbits, Virginia, USA. Emerg Infect Dis 17: 2047-2049.

Cossaboom CM, Cordoba L, Sanford BJ, Pineyro P, Kenney SP, Dryman BA, Wang Y, Meng XJ. 2012. Cross-species infection of pigs with a novel rabbit, but not rat, strain of hepatitis E virus isolated in the United States. J Gen Virol 93: $1687-1695$. 
* Cullen JM, Lemon SM. 2018. Comparative pathology of hepatitis A virus and hepatitis E virus infection. Cold Spring Harb Perspect Med doi: 10.1101/cshperspect.a033456.

* Dalton HR, Izopet J. 2018. Transmission and epidemiology of hepatitis E virus genotype 3 and 4 infections. Cold Spring Harb Perspect Med doi: 10.1101/cshperspect. a032144.

Dalton HR, Bendall RP, Keane FE, Tedder RS, Ijaz S. 2009. Persistent carriage of hepatitis $E$ virus in patients with HIV infection. N Engl J Med 361: 1025-1027.

Debing Y, Mishra N, Verbeken E, Ramaekers K, Dallmeier K, Neyts J. 2016. A rat model for hepatitis E virus. Dis Model Mech 9: 1203-1210.

Di Bartolo I, De Sabato L, Marata A, Martinelli N, Magistrali CF, Monini M, Ponterio E, Ostanello F, Ruggeri FM. 2016. Serological survey of hepatitis E virus infection in farmed and pet rabbits in Italy. Arch Virol 161: 1343-1346.

Drexler JF, Seelen A, Corman VM, Fumie Tateno A, Cottontail V, Melim Zerbinati R, Gloza-Rausch F, Klose SM, Adu-Sarkodie Y, Oppong SK, et al. 2012. Bats worldwide carry hepatitis $\mathrm{E}$ virus-related viruses that form a putative novel genus within the family Hepeviridae. J Virol 86: 9134-9147.

Emerson SU, Purcell RH. 2003. Hepatitis E virus. Rev Med Virol 13: 145-154.

Gardinali NR, Guimaraes JR, Melgaco JG, Kevorkian YB, Bottino FO, Vieira YR, da Silva AC, Pinto DP, da Fonseca LB, Vilhena LS, et al. 2017. Cynomolgus monkeys are successfully and persistently infected with hepatitis E virus genotype 3 (HEV-3) after long-term immunosuppressive therapy. PLOS ONE 12: 0174070.

Guan D, Li W, Su J, Fang L, Takeda N, Wakita T, Li TC, Ke C. 2013. Asian musk shrew as a reservoir of rat hepatitis $\mathrm{E}$ virus, China. Emerg Infect Dis 19: 1341-1343.

Halbur PG, Kasorndorkbua C, Gilbert C, Guenette D, Potters MB, Purcell RH, Emerson SU, Toth TE, Meng XJ. 2001. Comparative pathogenesis of infection of pigs with hepatitis E viruses recovered from a pig and a human. $J$ Clin Microbiol 39: 918-923.

Hammerschmidt F, Schwaiger K, Dahnert L, Vina-Rodriguez A, Hoper D, Gareis M, Groschup MH, Eiden M 2017. Hepatitis E virus in wild rabbits and European brown hares in Germany. Zoonoses Public Health 64: 612-622.

Haqshenas G, Shivaprasad HL, Woolcock PR, Read DH, Meng XJ. 2001. Genetic identification and characterization of a novel virus related to human hepatitis $\mathrm{E}$ virus from chickens with hepatitis-splenomegaly syndrome in the United States. J Gen Virol 82: 2449-2462.

* Hirai-Yuki A, Whitmire JK, Joyce M, Tyrrell DL, Lemon SM. 2018. Murine models of hepatitis A virus infection. Cold Spring Harb Perspect Med doi: 10.1101/cshperspect. a031674.

Hong Y, He ZJ, Tao W, Fu T, Wang YK, Chen Y. 2015. Experimental infection of Z:ZCLA Mongolian gerbils with human hepatitis E virus. World J Gastroenterol 21: 862-867.

Huang FF, Sun ZF, Emerson SU, Purcell RH, Shivaprasad HL, Pierson FW, Toth TE, Meng XJ. 2004. Determination and analysis of the complete genomic sequence of avian hepatitis E virus (avian HEV) and attempts to infect rhesus monkeys with avian HEV. J Gen Virol 85: 1609-1618.

Jirintai S, Jinshan, Tanggis, Manglai D, Mulyanto, Takahashi M, Nagashima S, Kobayashi T, Nishizawa T, Okamoto H. 2012. Molecular analysis of hepatitis $\mathrm{E}$ virus from farm rabbits in Inner Mongolia, China and its successful propagation in A549 and PLC/PRF/5 cells. Virus Res 170: 126 137.

Jirintai S, Tanggis, Mulyanto, Suparyatmo JB, Takahashi M, Kobayashi T, Nagashima S, Nishizawa T, Okamoto $\mathrm{H}$. 2014. Rat hepatitis E virus derived from wild rats (Rattus rattus) propagates efficiently in human hepatoma cell lines. Virus Res 185: 92-102.

Johne R, Heckel G, Plenge-Bönig A, Kindler E, Maresch C, Reetz J, Schielke A, Ulrich RG. 2010a. Novel hepatitis E virus genotype in Norway rats, Germany. Emerg Infect Dis 16: 1452-1455.

Johne R, Plenge-Bonig A, Hess M, Ulrich RG, Reetz J, Schielke A. 2010b. Detection of a novel hepatitis E-like virus in faeces of wild rats using a nested broad-spectrum RT-PCR. J Gen Virol 91: 750-758.

Johne R, Dremsek P, Reetz J, Heckel G, Hess M, Ulrich RG. 2014. Hepeviridae: An expanding family of vertebrate viruses. Infect Genet Evol 27: 212-229.

Kamar N, Selves J, Mansuy JM, Ouezzani L, Peron JM, Guitard J, Cointault O, Esposito L, Abravanel F, Danjoux M, et al. 2008. Hepatitis E virus and chronic hepatitis in organ-transplant recipients. N Engl J Med 358: 811-817.

Kamar N, Izopet J, Dalton HR. 2013. Chronic hepatitis E virus infection and treatment. J Clin Exp Hepatol 3: 134140.

* Kenney SP, Meng X-J. 2018. Hepatitis E virus genome structure and replication strategy. Cold Spring Harb Perspect Med doi: 10.1101/cshperspect.a031724.

Khuroo MS, Teli MR, Skidmore S, Sofi MA, Khuroo MI. 1981. Incidence and severity of viral hepatitis in pregnancy. Am J Med 70: 252-255.

Krog JS, Breum SO, Jensen TH, Larsen LE. 2013. Hepatitis E virus variant in farmed mink, Denmark. Emerg Infect Dis 19: 2028-2030.

* Lanford RE, Walker CM, Lemon SM. 2018. Nonhuman primate models of hepatitis A virus and hepatitis $\mathrm{E}$ virus infections. Cold Spring Harb Perspect Med doi: 10.1101/ cshperspect.a031815.

le Coutre P, Meisel H, Hofmann J, Rocken C, Vuong GL, Neuburger S, Hemmati PG, Dorken B, Arnold R. 2009. Reactivation of hepatitis $E$ infection in a patient with acute lymphoblastic leukaemia after allogeneic stem cell transplantation. Gut 58: 699-702.

Lee GH, Tan BH, Teo EC, Lim SG, Dan YY, Wee A, Aw PP, Zhu Y, Hibberd ML, Tan CK, et al. 2015. Chronic infection with camelid hepatitis $\mathrm{E}$ virus in a liver-transplant recipient who regularly consumes camel meat and milk. Gastroenterology 150: 355-357.e3.

Li TC, Zhang J, Shinzawa H, Ishibashi M, Sata M, Mast EE, Kim K, Miyamura T, Takeda N. 2000. Empty virus-like particle-based enzyme-linked immunosorbent assay for antibodies to hepatitis E virus. J Med Virol 62: 327-333.

Li TC, Suzaki Y, Ami Y, Dhole TN, Miyamura T, Takeda N. 2004. Protection of cynomolgus monkeys against HEV 
infection by oral administration of recombinant hepatitis E virus-like particles. Vaccine 22: 370-377.

Li TC, Chijiwa K, Sera N, Ishibashi T, Etoh Y, Shinohara Y, Kurata Y, Ishida M, Sakamoto S, Takeda N, et al. 2005. Hepatitis E virus transmission from wild boar meat. Emerg Infect Dis 11: 1958-1960.

Li TC, Suzaki Y, Ami Y, Tsunemitsu H, Miyamura T, Takeda N. 2008. Mice are not susceptible to hepatitis E virus infection. J Vet Med Sci 70: 1359-1362.

Li W, Sun Q, She R, Wang D, Duan X, Yin J, Ding Y. 2009. Experimental infection of Mongolian gerbils by a genotype 4 strain of swine hepatitis E virus. J Med Virol 81: 1591-1596.

Li TC, Yoshimatsu K, Yasuda SP, Arikawa J, Koma T, Kataoka M, Ami Y, Suzaki Y, Mai le TQ, Hoa NT, et al. 2011. Characterization of self-assembled virus-like particles of rat hepatitis $\mathrm{E}$ virus generated by recombinant baculoviruses. J Gen Virol 92: 2830-2837.

Li TC, Ami Y, Suzaki Y, Yasuda SP, Yoshimatsu K, Arikawa J, Takeda N, Takaji W. 2013a. Characterization of full genome of rat hepatitis E virus strain from Vietnam. Emerg Infect Dis 19: 115-118.

Li W, Guan D, Su J, Takeda N, Wakita T, Li TC, Ke CW. 2013b. High prevalence of rat hepatitis $\mathrm{E}$ virus in wild rats in China. Vet Microbiol 165: 275-280.

Li TC, Yang T, Yoshizaki S, Ami Y, Suzaki Y, Ishii K, Haga K, Nakamura T, Ochiai S, Takaji W, et al. 2015a. Construction and characterization of an infectious cDNA clone of rat hepatitis E virus. J Gen Virol 96: 1320-1327.

Li TC, Yonemitsu K, Terada Y, Takeda N, Takaji W, Maeda K. 2015b. Ferret hepatitis E virus infection in Japan. Japanese Journal Infectious Diseases 68: 60-62.

Li TC, Yoshizaki S, Ami Y, Suzaki Y, Yang T, Takeda N, Takaji W. 2015c. Monkeys and rats are not susceptible to ferret hepatitis $\mathrm{E}$ virus infection. Intervirology 30: 139-142.

Li TC, Yang T, Yoshizaki S, Ami Y, Suzaki Y, Ishii K, Kishida N, Shirakura M, Asanuma H, Takeda N, et al. 2016a. Ferret hepatitis $\mathrm{E}$ virus infection induces acute hepatitis and persistent infection in ferrets. Vet Microbiol 183: 3036.

Li TC, Yoshizaki S, Ami Y, Suzaki Y, Johne R, Wakita T. 2016b. No evidence of rat hepatitis E virus excretion into urine of rats. Jpn J Infect Dis 70: 305-307.

Li TC, Yoshizaki S, Yang T, Kataoka M, Nakamura T, Ami Y, Yuriko S, Takeda N, Wakita T. 2016c. Production of infectious ferret hepatitis $\mathrm{E}$ virus in a human hepatocarcinoma cell line PLC/PRF/5. Virus Res 213: 283-288.

Li TC, Zhou X, Yoshizaki S, Ami Y, Suzaki Y, Nakamura T, Takeda N, Wakita T. 2016d. Production of infectious dromedary camel hepatitis $\mathrm{E}$ virus by a reverse genetic system: Potential for zoonotic infection. J Hepatol 65: 1104-1111.

Li TC, Yoshizaki S, Kataoka M, Ami Y, Suzaki Y, Doan YH, Haga K, Ishii K, Takeda N, Wakita T. 2017. Genetic and physicochemical analyses of a novel ferret hepatitis E virus, and clinical signs of infection after birth. Infect Genet Evol 51: 153-159.

Lin J, Norder H, Uhlhorn H, Belák S, Widén F. 2014. Novel hepatitis E like virus found in Swedish moose. J Gen Virol 95: $557-570$
Liu Z, Meng J, Sun X. 2008. A novel feature-based method for whole genome phylogenetic analysis without alignment: Application to HEV genotyping and subtyping. Biochem Biophys Res Commun 368: 223-230.

Liu P, Bu QN, Wang L, Han J, Du RJ, Lei YX, Ouyang YQ, Li J, Zhu YH, Lu FM, et al. 2013. Transmission of hepatitis E virus from rabbits to cynomolgus macaques. Emerg Infect Dis 19: 559-565.

Liu B, Sun Y, Du T, Chen Y, Wang X, Huang B, Li H, Nan Y, Xiao S, Zhang G, et al. 2017. Rabbit hepatitis $E$ virus is an opportunistic pathogen in specific-pathogen-free rabbits with the capability of cross-species transmission. Vet Microbiol 201: 72-77.

Ma H, Zheng L, Liu Y, Zhao C, Harrison TJ, Ma Y, Sun S, Zhang J, Wang Y. 2010. Experimental infection of rabbits with rabbit and genotypes 1 and 4 hepatitis $\mathrm{E}$ viruses. PLOS ONE 5: e9160.

Magden J, Takeda N, Li T, Auvinen P, Ahola T, Miyamura T, Merits A, Kaariainen L. 2001. Virus-specific mRNA capping enzyme encoded by hepatitis $\mathrm{E}$ virus. $J$ Virol 75: 6249-6255.

Marek A, Bilic I, Prokofieva I, Hess M. 2010. Phylogenetic analysis of avian hepatitis $\mathrm{E}$ virus samples from European and Australian chicken flocks supports the existence of a different genus within the Hepeviridae comprising at least three different genotypes. Vet Microbiol 145: 54-61.

Meng XJ. 2010. Hepatitis E virus: Animal reservoirs and zoonotic risk. Vet Microbiol 140: 256-265.

Meng XJ, Halbur PG, Shapiro MS, Govindarajan S, Bruna JD, Mushahwar IK, Purcell RH, Emerson SU. 1998. Genetic and experimental evidence for cross-species infection by swine hepatitis E virus. J Virol 72: 9714-9721.

Meng XJ, Anderson DA, Arankalle VA, Emerson SU, Harrison TJ, Jameel S, Okamoto H. 2012. Hepeviridae. In Virus taxonomy: Ninth report of the International Committee on Taxonomy of Viruses (ed. King AMQ, Lefkowitz E, Adams MJ, Carstens EB), pp. 1021-1028. Elsevier, London.

Mercer DF, Schiller DE, Elliott JF, Douglas DN, Hao C, Rinfret A, Addison WR, Fischer KP, Churchill TA, Lakey JR, et al. 2001. Hepatitis C virus replication in mice with chimeric human livers. Nat Med 7: 927-933.

Nagashima S, Takahashi M, Jirintai, Tanaka T, Yamada K, Nishizawa T, Okamoto H. 2011. A PSAP motif in the $\mathrm{ORF} 3$ protein of hepatitis $\mathrm{E}$ virus is necessary for virion release from infected cells. J Gen Virol 92: 269-278.

Nelson KE, Kmush B, Labrique AB. 2011. The epidemiology of hepatitis $\mathrm{E}$ virus infections in developed countries and among immunocompromised patients. Expert Rev Anti Infect Ther 9: 1133-1148.

* Nelson KE, Labrique AB, Kmush BL. 2018. Epidemiology of genotype 1 and 2 hepatitis E virus infections. Cold Spring Harb Perspect Med doi: 10.1101/cshperspect.a031732.

Ollier L, Tieulie N, Sanderson F, Heudier P, Giordanengo V, Fuzibet JG, Nicand E. 2009. Chronic hepatitis after hepatitis $\mathrm{E}$ virus infection in a patient with non-Hodgkin lymphoma taking rituximab. Ann Intern Med 150: 430431.

Purcell RH, Engle RE, Rood MP, Kabrane-Lazizi Y, Nguyen HT, Govindarajan S, St Claire M, Emerson SU. 2011. Hepatitis E virus in rats, Los Angeles, California, USA. Emerg Infect Dis 17: 2216-2222. 
T.-C. Li and T. Wakita

Purcell RH, Engle RE, Govindarajan S, Herbert R, St Claire M, Elkins WR, Cook A, Shaver C, Beauregard M, Swerczek J, et al. 2013. Pathobiology of hepatitis E: Lessons learned from primate models. Emerg Microbes Infect 2: e9.

Raj VS, Smits SL, Pas SD, Provacia LB, Moorman-Roest H, Osterhaus AD, Haagmans BL. 2012. Novel hepatitis E virus in ferrets, the Netherlands. Emerg Infect Dis $\mathbf{1 8}$ 1369-1370.

Rein DB, Stevens GA, Theaker J, Wittenborn JS, Wiersma ST. 2012. The global burden of hepatitis E virus genotypes 1 and 2 in 2005. Hepatology 55: 988-997.

Reuter G, Boros A, Matics R, Kapusinszky B, Delwart E Pankovics P. 2016. Divergent hepatitis E virus in birds of prey, common kestrel (Falco tinnunculus) and redfooted falcon (F. vespertinus), Hungary. Infect Genet Evol 43: 343-346.

Reyes GR, Purdy MA, Kim JP, Luk KC, Young LM, Fry KE, Bradley DW. 1990. Isolation of a cDNA from the virus responsible for enterically transmitted non-A, non-B hepatitis. Science 247: 1335-1339.

Sayed IM, Foquet L, Verhoye L, Abravanel F, Farhoudi A, Leroux-Roels G, Izopet J, Meuleman P. 2017. Transmission of hepatitis E virus infection to human-liver chimeric FRG mice using patient plasma. Antiviral Res 141: 150154.

Shukla P, Nguyen HT, Torian U, Engle RE, Faulk K, Dalton HR, Bendall RP, Keane FE, Purcell RH, Emerson SU. 2011. Cross-species infections of cultured cells by hepatitis E virus and discovery of an infectious virus-host recombinant. Proc Natl Acad Sci 108: 2438-2443.

* Smith DB, Simmonds P. 2018. Classification and genomic diversity of enterically transmitted hepatitis viruses. Cold Spring Harb Perspect Med doi: 10.1101/cshperspect. a031880.

Smith DB, Simmonds P, Jameel S, Emerson SU, Harrison TJ, Meng XJ, Okamoto H, Van der Poel WH, Purdy MA. 2014. Consensus proposals for classification of the family Hepeviridae. J Gen Virol 95: 2223-2232.

Takahashi M, Nishizawa T, Nagashima S, Jirintai S, Kawakami M, Sonoda Y, Suzuki T, Yamamoto S, Shigemoto K, Ashida K, et al. 2014. Molecular characterization of a novel hepatitis E virus (HEV) strain obtained from a wild boar in Japan that is highly divergent from the previously recognized HEV strains. Virus Res 180: 59-69.

Tam AW, Smith MM, Guerra ME, Huang CC, Bradley DW Fry KE, Reyes GR. 1991. Hepatitis E virus (HEV): Molecular cloning and sequencing of the full-length viral genome. Virology 185: 120-131.

Tanaka T, Takahashi M, Kusano E, Okamoto H. 2007. Development and evaluation of an efficient cell-culture system for hepatitis E virus. J Gen Virol 88: 903-911.
Tei S, Kitajima N, Takahashi K, Mishiro S. 2003. Zoonotic transmission of hepatitis $\mathrm{E}$ virus from deer to human beings. Lancet 362: 371-373.

Tsarev SA, Tsareva TS, Emerson SU, Rippy MK, Zack P, Shapiro M, Purcell RH. 1995. Experimental hepatitis E in pregnant rhesus monkeys: Failure to transmit hepatitis $\mathrm{E}$ virus (HEV) to offspring and evidence of naturally acquired antibodies to HEV. J Infect Dis 172: 31-37.

van de Garde MD, Pas SD, van der Net G, de Man RA, Osterhaus AD, Haagmans BL, Boonstra A, Vanwolleghem T. 2016. Hepatitis E virus (HEV) genotype 3 infection of human liver chimeric mice as a model for chronic HEV infection. J Virol 90: 4394-4401.

van de Garde MDB, Pas SD, van Oord GW, Gama L, Choi Y, de Man RA, Boonstra A, Vanwolleghem T. 2017. Interferon- $\alpha$ treatment rapidly clears hepatitis $\mathrm{E}$ virus infection in humanized mice. Sci Rep 7: 8267.

Woo PC, Lau SK, Teng JL, Tsang AK, Joseph M, Wong EY, Tang Y, Sivakumar S, Xie J, Bai R, et al. 2014. New hepatitis E virus genotype in camels, the Middle East. Emerg Infect Dis 20: 1044-1048.

Xia J, Liu L, Wang L, Zhang Y, Zeng H, Liu P, Zou Q, Wang L, Zhuang H. 2015. Experimental infection of pregnant rabbits with hepatitis $\mathrm{E}$ virus demonstrating high mortality and vertical transmission. J Viral Hepat 22: 850-857.

Yamamoto H, Suzuki J, Matsuda A, Ishida T, Ami Y, Suzaki Y, Adachi I, Wakita T, Takeda N, Li TC. 2012. Hepatitis E virus outbreak in monkey facility, Japan. Emerg Infect Dis 18: 2032-2034.

Yang T, Kataoka M, Ami Y, Suzaki Y, Kishida N, Shirakura M, Imai M, Asanuma H, Takeda N, Wakita T, et al. 2013. Characterization of self-assembled virus-like particles of ferret hepatitis E virus generated by recombinant baculoviruses. J Gen Virol 94: 2647-2656.

Yu C, Boon D, McDonald SL, Myers TG, Tomioka K, Nguyen H, Engle RE, Govindarajan S, Emerson SU, Purcell RH. 2010. Pathogenesis of hepatitis E virus and hepatitis $\mathrm{C}$ virus in chimpanzees: Similarities and differences. J Virol 84: 11264-11278.

Yu W, Yang C, Bi Y, Long F, Li Y, Wang J, Huang F. 2016. Characterization of hepatitis $\mathrm{E}$ virus infection in tree shrew (Tupaia belangeri chinensis). BMC Infect Dis 16: 80.

Yugo DM, Cossaboom CM, Meng XJ. 2014. Naturally occurring animal models of human hepatitis $\mathrm{E}$ virus infection. ILAR J 55: 187-199.

Zhao C, Ma Z, Harrison TJ, Feng R, Zhang C, Qiao Z, Fan J, $\mathrm{Ma} \mathrm{H}$, Li M, Song A, et al. 2009. A novel genotype of hepatitis $\mathrm{E}$ virus prevalent among farmed rabbits in China. J Med Virol 81: 1371-1379. 


\section{$\&_{\mathrm{CSH}}^{\infty} \&$ Cold Spring Harbor

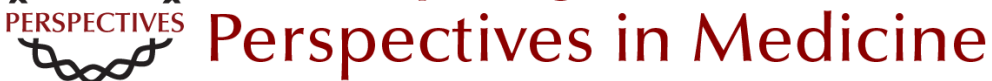

\section{Small Animal Models of Hepatitis E Virus Infection}

Tian-Cheng Li and Takaji Wakita

Cold Spring Harb Perspect Med 2019; doi: 10.1101/cshperspect.a032581 originally published online May 7, 2018

\section{Subject Collection Enteric Hepatitis Viruses}

Hepatitis A Virus Genome Organization and Replication Strategy

Kevin L. McKnight and Stanley M. Lemon

Adaptive Immune Responses in Hepatitis A Virus and Hepatitis E Virus Infections

Christopher M. Walker

Small Animal Models of Hepatitis E Virus Infection Tian-Cheng Li and Takaji Wakita

Acute and Persistent Hepatitis E Virus Genotype 3 and 4 Infection: Clinical Features, Pathogenesis, and Treatment Nassim Kamar and Sven Pischke

Epidemiology of Genotype 1 and 2 Hepatitis E Virus Infections

Kenrad E. Nelson, Alain B. Labrique and Brittany L. Kmush

History of the Discovery of Hepatitis A Virus Stephen M. Feinstone

Epidemiology and Transmission of Hepatitis A Virus and Hepatitis E Virus Infections in the United States

Megan G. Hofmeister, Monique A. Foster and Eyasu H. Teshale

Stem Cell-Derived Culture Models of Hepatitis E Virus Infection

Viet Loan Dao Thi, Xianfang Wu and Charles M. Rice
Evolutionary Origins of Enteric Hepatitis Viruses Anna-Lena Sander, Victor Max Corman, Alexander N. Lukashev, et al.

Enterically Transmitted Non-A, Non-B Hepatitis and the Discovery of Hepatitis $\mathrm{E}$ Virus

Stanley M. Lemon and Christopher M. Walker

Natural History, Clinical Manifestations, and

Pathogenesis of Hepatitis E Virus Genotype 1 and

2 Infections

Rakesh Aggarwal and Amit Goel

Hepatitis A Virus and Hepatitis E Virus: Emerging and Re-Emerging Enterically Transmitted

Hepatitis Viruses

Stanley M. Lemon and Christopher M. Walker

Hepatitis A Virus Capsid Structure

David I. Stuart, Jingshan Ren, Xiangxi Wang, et al.

Comparative Pathology of Hepatitis A Virus and Hepatitis E Virus Infection John M. Cullen and Stanley M. Lemon

Innate Immunity to Enteric Hepatitis Viruses Zongdi Feng and Stanley M. Lemon

Nonhuman Primate Models of Hepatitis A Virus and Hepatitis E Virus Infections

Robert E. Lanford, Christopher M. Walker and

Stanley M. Lemon

For additional articles in this collection, see http://perspectivesinmedicine.cshlp.org/cgi/collection/ 